\title{
LITERARY FREEDOM AND THE NEED TO INTER-LOGUE
}

\author{
Neil Khor
}

Mohd Khaldun Malek

\begin{abstract}
This commentary piece is based upon an article published in Malaysiakini $^{1}$ and the reactions that resulted from it. The article is not a literary appraisal of the novel. It is an attempt to understand the ensuing controversy and plead for literary freedom. It is not the writer's place to decide whether the novel is suitable as classroom material but this piece explains the special qualities of literary work and the ethnic politics in Malaysia that is the real casus belli for the controversy.
\end{abstract}

Keywords: Interlok, ethnic politics, controversial literary work, school textbook

\section{Introduction}

Novels and other literary works are the production of the writer's imagination, his interaction with the society around him and, in National Laureate Abdullah Hussain's case, aspirational. It should not be surprising that Literature has 
always been accompanied by controversy. This is largely to do with the fact that great literary works often challenges the way we look at things, and forces us to reconsider the way we look at the world. Inevitably, this may promote debate and disagreement-a critical ingredient, in our opinion, of any healthy society.

Interlok is by no means Abdullah's best work and the plot a bit contrived. Its theme is a plea for greater understanding and cooperation between the different ethnic groups, elements which were particularly relevant to its readers at the time of its publication in 1971. This was the generation that had recently survived a World War, the brutal Japanese Occupation, a Communist-led insurgency; people who were adjusting to independence and self-rule. In an attempt to look back at the turn of the 20th century, which is the setting for the novel and within the living memory of his readers, Abdullah was attempting to revisit the origins of this newly independent and multi-ethnic nation.

Of course, literary works cannot be free of controversy as a novel is a concentrated piece of work derived from the writer's lived experience; it can at times be "inaccurate" or "too broadly-based". The recent controversy of A. Samad Said's poem "Unggun Bersih" is another example of the special qualities of a literary work. It evokes feelings that bring us into a heightened state of realisation. Interlok is no different and it should not surprise us that the novel has given rise to strong feelings. In fact, some parts of the novel were deemed "offensive" to certain groups who felt that it was unfair in its treatment owing to the construction of certain characters from this group, with stereotypical qualities. Nevertheless, Interlok attempted to lay bare the problems and failings of a postcolonial society.

Neither was the novel unusual for its time. Other literary works of that vintage includes works of Lloyd Fernando like Scorpion Orchid (1976) which used allegory (where characters represented certain values or types) to deal and comment upon the situation in Malaysia after the May 13 Race Riots. This was a period of flux where a new national identity, one based upon Malay culture and Bahasa Malaysia as the National Language, was being forged. A decade earlier, Harper Lee had published To Kill a Mockingbird (1960); a novel that also employed an allegorical framework to investigate the psychology of racism. That novel also proved equally controversial for its engagement with some of the more disquieting aspects of American society at the time. ${ }^{2}$ 
Coming back to the issue at hand, Interlok was not necessarily more radical than other works of its time. It can be said that it is an attempt by a writer to deal with issues of identity that a multiracial Malaysia represented. It would, I suspect, be treated quite differently if it were compared with the works of Malaysians of different social, economic and racial background at the time and how all of them dealt with the complexity of identity formation that nation-building required. ${ }^{3}$

\section{New Life as School Textbook}

Thus, for more than four decades, the novel lived a quiet life. All that changed when the novel was selected to be a school textbook and thus began Interlok's controversial life. To fit into the reading capacity of Malaysian high school students, the novel had to be "edited" to a suitable length. This was to be the beginning of a slippery and controversial path. Perhaps, students nowadays cannot spend the time to read a novel in its entirety although there was no such squeamishness in the 1980s when this writer was in secondary school. Anyway, to fit the mould of a tolerant multi-ethnic society, these editors also decided to expunge what they considered the more controversial bits out. The door was now wide open for even more criticism.

In post 2008 Malaysia, after the 12th General Election saw the Barisan Nasional Government losing its two thirds parliamentary majority, Malaysians of all ethnicities have become more critical of the government's affirmative action policies. The government was partly to blame for this having gone to town building expectations of a fully developed nation. Surely, the argument went, in a developed country, there would be little need for affirmative action based upon ethnicity. We are all Malaysians.

Such ethnic issues-especially those that arise from a rather unequal society in terms of inter-ethnic and intra-ethnic disparity in income and social mobility-have been swept under the proverbial carpet. They remain unresolved burning social issues. This is especially true for the Malaysian Indian community, many of whom are of Tamil origin, who emigrated to work in British-owned plantations and were particularly unhappy with the government's affirmative action policy not benefitting them as much as it should. The Hindraf Movement had rocked Malaysia prior to the 2008 General Elections and since then, anything to do with Malaysian Indians has been particularly explosive. ${ }^{4}$ 
Thus when an ethnic Indian-Malaysian parent found certain passages in Interlok insulting, a complaint was lodged with the Education Ministry. ${ }^{5}$ This complaint was based on passagges in the novel being insensitve. This is reflected in the opinions expressed in various blogs and digital publications. Abdullah, in some of the more heated pieces in the cyber-conference that took place, was "misreading history". References to the Dalit class were made in the novel and the word "pariah" had been used to refer to Indian characters. In India today, it is no longer permissible to discriminate against Dalits and rightly so. But such enlightened policies only came into place in India quite recently.

In the novel, all characters still remember the country of their origins and Malay characters are also aware of their "merantau" origins. The Malaysia they knew was still very much Tanah Melayu (or British Malaya). We Malaysians as readers "reacting" to the novel also often forget we come from different communities living in the three Crown Colonies, four Federated Malay States and five Unfederated Malay States as well as two Borneo states with very different systems of governance. It is not uncommon for us to have inherited different impressions about Malaysia based upon the different experiences our elders experienced. Abdullah cannot be expected to write a novel that encompassed all these varied experiences. It is this first misconception-about the role and qualities of fiction-that is the root cause of all the future misunderstandings about the novel. A novel is not an all-encompassing historical encyclopedia and a writer writes from his own personal experiences, his own history and perspective.

However, because the characters were allegorical, the inference is that all ethnic Indians are "pariah". This is no doubt, a gross oversimplification. Ironically, if such portrayals of the Indian caste system had not been exposed, there would have been little chance of any reforms to that social system. Nonetheless, few of Interlok's critics were ready to give the novel the benefit of the doubt nor were they interested in the reality of Malaya at that time. Their criticisms and angry reactions stemmed from current real and perceived grievances. It did not help that before and subsequent to the furore over the novel, several teachers were hauled up for allegedly making "racists" remarks ${ }^{6}$ degrading non-Malay students.

The reactions to an article in Malaysiakini demonstrate the highly charged and emotional state of the critics. ${ }^{7}$ In fact, in 2003, the Indian-Muslim community brought up the issue of the word "Kling". They found the word derogatory and wanted it erased from the Kamus Dewan. Yet historically, 
"Kling" referred to peoples from Kalinga in Central Eastern India. ${ }^{8}$ However, owing to their position in the colonial pecking order, "Kling" has come to have negative connotations. It is the same with the word "pariah", which has entered into the English language from the caste system of South India with all the negative connotations intact. ${ }^{9}$

\section{Debate on Literary Work}

In most other countries, repressive regimes being the exception, people often debate and discuss difficult and controversial literary works. If we were to censor and edit out offending passages then we have to remove literature all together for some community somewhere is bound to be "offended". This was the exact decision made by China's first emperor Chin Shih Hwang-Di, who ordered all books and works that did not agree with his worldview destroyed.

Imagine Shakespeare without Merchant of Venice because the Jews find the characterisation of Shylock “offensive". Similarly, Jane Austen's novels should not be part of any literature syllabus because it is offensive to Third World readers. As Terry Eagelton has eloquently argued, Austen's novels provide a false picture of Western society. In fact, before arriving in the colonies as educational texts, Jane Austen's novels were first used as "literary texts" in the industrial towns of England to help provide the "masses" with the idea and "benefits" of an ordered English society. ${ }^{10}$ Yet, without those novels, we would be poorer for our lack of understanding of how one aspect of cultural imperialism works.

Debating and discussing difficult and controversial literary works are intrinsically valuable in themselves. It needs to be part of a larger public culture that allows us to reflect, with some measure of seriousness and honesty about the values we think are important. Controversies surrounding the uses and abuses of literature are nothing new. In recent years for example, there have been even suggestions in Germany that Heidegger's philosophical writings should be banned because of his association with the Nazis during the Second World War. No doubt, while history is littered with painful episodes that we may wish to forget, it reminds us of our mistakes of the past. But it is these mistakes that are most valuable, because they allow us to reflect on our collective memories; to learn from the past and to cherish the good we have in the present. As George Santayana reminds us, those who have forgotten the past, are bound to repeat it. 
Works of literature, like other forms of cultural expression, reflect the prevailing sentiments of a given society at a certain point of time in their history. While we may or may not agree with such values, it is the result of these collective experiences that allow us to reflect thoughtfully on what has gone on before and learn from past mistakes. Hence, if there are some passages in Interlok that some segments of Malaysian society finds offensive, the answer is not the wholesale rejection of the novel or the censoring of the so-called "offensive" passages but an intelligent conversation or critical appraisal of the novel. There is nothing wrong for teachers or students to disagree with the writer.

\section{Reflections about the Controversy}

One of the main attacks against the novel is that it does not merit being a school textbook. This commentary piece is not interested in such valuejudging. Ironically, what is not said is that students might misunderstand these passages because there are prejudiced teachers or incompetent ones. If that is the underlying fear, the answer is not to banish the novel from schools but to ensure teachers possess the required levels of competencies and professionalism. What would be tragic is if inevitably, it is political expediency that determines what should or should not be taught in our schools.

Unfortunately, a government that tries to please everybody ends up pleasing nobody. Instead of rising above petty politics, both the government and opposition parties have tried to gain political mileage from the issue. The battle lines are drawn so clearly that the responses are painfully predictable. Groups purportedly representing Malaysian Indians are forced into a corner whilst Malay NGOs are lined up opposite them. Racial politics is a zerosum game and in this case there are no winners.

To us Interlok is a Malaysian novel describing a particular view of the country from one writer's perspective. It happens to be written in Bahasa Malaysia or Bahasa Melayu but it is certainly not only a Malay novel. In short, any defence of Interlok should be on the basis that this is a literary work.

Yet the "offending" novel remains in the classrooms with its integrity as a literary work compromised. It is truly sad that whilst the novel is about the creation of a platform for different communities to talk and get to know each other; it is being censored because decision-makers are blinkered. 
Amazingly we have all managed to ignore the elephant in the room. By typecasting Interlok as being offensive to Malaysian Indians, these critics are giving strength to stereotypes about the very community we seek to expunge. Instead of being defensive, the government should admit that it will take time to correct the imbalances or weaknesses in the implementation of poverty eradication policies. In short, avoid sloganeering or simplistic gestures like erasing offending passages or words from novels. Instead, demonstrate concrete steps taken to address this community's grievances.

At the same time, Interlok provides a perfect platform to explain the complexity of managing a country with diverse communities at different levels of economic and social development. The government should not be shy to insist that it is not systematically marginalising any one community. On a per-capita basis, Bumiputeras continue to be the largest group of hardcore poor. While race continues to play such a prominent role in Malaysia's public imagination, there is very little room to talk about the real structural problems-social and economic displacement, access and opportunity-that continue to undermine Malaysian society.

The greater worry to our mind, is less to do with the Interlok controversy but the way in which the political landscape continues to be determined by the kind of narrow minded politicking of the various political partiesregardless of their orientation. This is not a plea to take the issues of race and ethnicity out of the picture, but to humbly suggest that much more can be had if these issues were discussed intelligently and with a sense of understanding and compassion.

\section{Conclusion}

Therefore, I suspect that all Malaysians would have been more reassured if the government had announced that steps are being taken to improve the lives of all Malaysians in the lower income bracket rather than hoping the insecurities felt today would go away just by censoring a novel written forty years ago. If we cannot come together as a nation and rise above petty politics, our prospects as a nation are dim indeed. Similarly, if segments of the citizenry of this country feel so insecure socially and economically as to react in such strong outbursts of emotions then something must be wrong.

Ultimately, our single biggest mistake is not heeding the message our National Laureate is telling us in this novel written some forty years ago: 
if Malaysia is to work as a nation, we have to talk to each other and not at one another. We need to "inter-logue" because, whether we like it or not, we are all part of one fabric, our histories connected.

\section{Notes}

1 The article was published on 11 February 2011. Please see http://www.malaysiakini.com/news/155359.

2 The 1960s is often associated with the civil rights movement characterized by protest marches against ethnic segregation in public buses, access to public education and other facets of American life.

3 Neil Khor has explored how Anglophone Malaysian writers deal with nationhood in their novels, please see Neil Khor, "Lloyd Fernando's Green is the Colour \& KS Maniam's A Far Country: Two Approaches to Nationhood", SARE 2002.

4 HINDRAF or the Human Rights Party Malaysia "Focusing to put the Indian Working Class into the National Mainstream". In 2007, Hindraf organised a major rally in Kuala Lumpur to highlight the plight of the Indian working class. It is interesting that the protestors wanted to bring a lawsuit against the Queen of England for Britain's role in bringing Indians to Malaysia; an indication, perhaps, that the legacy of colonialism still haunts Malaysia 50 years after independence. More information about Hindraf please see: http://www.humanrightspartymalaysia.com/.

5 This has since developed into a nationwide campaign to have the novel removed as a school textbook. For more about National Interlok Action Team (NIAT), please see http://english.cpiasia.net/index. php?option $=$ com_content $\&$ view $=$ article $\&$ id $=2153 \&$ catid $=228 \&$ Itemid $=$ 196.

6 The Malaysian Insider reported that a school headmaster had alledgedly made racist remarks during school assembly. This was one of several cases reported by the press. Please see: http://www.themalaysianinsider.com/ malaysia/article/racist-principal-debate-signals-a-divided-nation/.

7 For a particularly interesting reaction, please see: http:/hartalmsm.wordpress. com/2011/03/28/why-are-some-indians-so-sensitive-asks-cambridge$\mathrm{phd} /$.

8 For a better appreciation about the word Kling, please read Sabri Zain's article: http://www.sabrizain.org/malaya/keling.htm \& for GAPENA's reactions to the controversy, please read: http://my.news.yahoo.com/malay-writers-askmalays-to-stop-questioning-kamus-20110418-000841-599.html. 
9 Pariah was literally derived from the Tamil Paraiyan (drummer), the largest of the lower caste Indians. See http://www.word-origins.com/definition/ pariah.html.

10 See Terry Eagleton, 1996. Literary Theory: An Introduction.

\section{References}

Abdullah Hussain, 1971. Interlok. Dewan Bahasa dan Pustaka: Kuala Lumpur.

Abdullah Hussain, 1996. Interlok. Dewan Bahasa dan Pustaka: Kuala Lumpur.

Eagleton, Terry, 1996. Literary Theory: An Introduction. Blackwell: United Kingdom.

Khor, Neil, 2002. "Lloyd Fernando's Green is the Colour and KS Maniam's in A Far Country: Two Approaches to Nationhood" in Southeast Asian Review of English. Kuala Lumpur. 